\title{
The sorption of organic compounds from water during technological start-up of carbon filters
}

\author{
Dorota Holc ${ }^{1, *}$, Alina Pruss $^{2}$, Matgorzata Komorowska-Kaufman ${ }^{2}$, Beata Mądrecka ${ }^{2}$, \\ and Zefiryn Cybulski ${ }^{3}$ \\ ${ }^{1}$ Poznan University of Technology, Faculty of Civil and Environmental Engineering, Institute of \\ Environmental Engineering, ul. Berdychowo 4, 60-965 Poznan, Poland; Envirotech Ltd. Co., \\ ul. Jana Kochanowskiego 7, 60-845 Poznan, Poland \\ ${ }^{2}$ Poznan University of Technology, Faculty of Civil and Environmental Engineering, Institute \\ of Environmental Engineering, ul. Berdychowo 4, 60-965 Poznan, Poland \\ ${ }^{3}$ Greater Poland Cancer, Microbiology Laboratory, ul. Garbary 15, 61-860 Poznan, Poland
}

\begin{abstract}
Natural waters contain organic substances that have a major impact on the quality of water, in particular on its organoleptic properties. They can also change its physical and chemical properties and have a negative impact on the technological processes used during water treatment. There is no doubt that organic substances contained in natural waters have to be removed during treatment processes in order to achieve concentrations consistent with the requirements concerning the quality of water intended for human consumption. A very effective method of organic compounds elimination from water is to use of biologically active filters (BAF). This article presents the results of pilot scale research on the effectiveness of removal of organic compounds from water using filtration through a bed of activated carbon filters, during their technological start-up. The obtained results showed high, more than $91 \%$ efficiency of reducing the content of organic compounds expressed by TOC, $\mathrm{COD}\left(\mathrm{KMnO}_{4}\right)$ and $\mathrm{UV}_{254}$ absorbance. The predominant process at the start of the use of carbon filters has been sorption. During the research, the development of biofilm in the filter bed was also controlled. The identification of microorganisms showed the presence of Gramnegative bacteria in the beds of both filter columns.
\end{abstract}

\section{Introduction}

Organic compounds found in natural waters can be divided into two categories: the first one includes natural organic matter, while the other organic compounds of anthropogenic origin. These compounds have a fundamental impact on the quality of water, in particular on its organoleptic properties, causing deterioration of water colour, odour and taste. They can also change the physicochemical properties of water and have a negative impact on technological processes during water treatment. In addition, their inadequate removal

*Corresponding author: dorota_holc@op.pl 
from water entering the water supply system may cause secondary pollution development, which in turn leads to poor water quality at the tap. It is therefore necessary to remove organic substances from water to achieve concentrations consistent with the requirements for the quality of water intended for human consumption [1-5].

The use of biologically active filters (BAF) to remove organic compounds from water gives very good results [6-8]. Biofiltration is also a way to ensure biological stability of tap water and reduce the doses of disinfectants $[3,9,10,11]$.

Removal of contaminants on the bed of biologically active filters takes place as a result of two parallel processes: adsorption and biodegradation $[9,12,13]$. The BAFs are filled with a filter bed characterized by a well-developed specific surface of grains and high porosity, which is a very good substrate for the proliferation of microorganisms. The most popular filling of such filters is activated carbon, which additionally has the ability to adsorb pollutants contained in the water. A constant supply of oxygen and nutrients is essential for the development of microorganisms in the deposit [9, 13]. The biofilm formed is capable of processing and elimination (biodegradation) of pollutants adsorbed in the pores and on the surface of the bed grains. At the beginning of the filters operation, when the biofilm-forming bacteria are in the adaptation period, dissolved organic matter is removed by way of physical adsorption. This start-up period may take from 2 to 3 months $[9,14]$. Due to continuous development of microorganisms, at a later stage the degree of dissolved organic matter removed through adsorption is gradually decreasing. The active sites of the bed grains are saturated and the rate of biological degradation increases considerably. With time, the biodegradation process taking place in the filter prevails over adsorption, which is also related to the exhaustion of the adsorptive capacity of activated carbon [9, 15, 16]. The microorganisms responsible for the metabolism of contaminants also extend the working time of the filter bed and limit the development of pathogenic microflora competing with it for food [17].

In this article, the authors present the results of their own research which is a continuation of the research initiated in April 2015. In April 2018, the authors having 3 years of experience in operating the pilot BAF installation, once again launched the research stand. The filter columns were filled again with fresh WG-12 activated carbon. This time, the filtration media were not activated through recirculation of backwashings from carbon filters operated on a technical scale $[6,7,16]$. From the beginning of the installation operation, tap water and water modified with humic compounds was filtered. The article will present the results obtained during the first stage of research, directly after the commissioning of BAFs, when the sorption process prevailed in the filters.

\section{Materials and methods}

The research was conducted on a pilot scale on the physical model of rapid filters at the Institute of Environmental Engineering of the Poznan University of Technology. The model consisted of two filter columns with an inner diameter of $100 \mathrm{~mm}$, filled with fresh WG-12 activated carbon. Constant temperature was maintained across the entire filter bed height thanks to the use of a water jacket - a pipe with an inner diameter of $140 \mathrm{~mm}$ filled with water. The water flowing through the pipe had a temperature equal to the temperature of the water subject to filtration. The total height of the filter bed was $2.10 \mathrm{~m}$. The research installation is shown in Figure 1. Water was supplied to both filtering columns at a flow rate of $20 \mathrm{dm}^{3} / \mathrm{h}$. Constant rate of filtration was provided by rotameters. The filter column 1 was supplied with tap water. The filter column 2 was flooded with modelled water, i.e. contaminated with biohumus $(100 \mathrm{ml}$ of biohumus $/ 1000 \mathrm{ml}$ of tap water). Biohumus is an organic fertilizer, rich in nutrients and microorganisms, derived from processed manure. Filter columns have been equipped with taps for collecting water 
samples evenly distributed throughout the entire vertical section of the bed. The samples were taken at the inflow of water to the filters and from the outflow, and at the depths of $45 \mathrm{~cm}, 85 \mathrm{~cm}, 125 \mathrm{~cm}, 165 \mathrm{~cm}$ and $205 \mathrm{~cm}$. Samples from the filtration columns' inflow and outflow were collected daily at the same time, from day 3 to day 40 of the system operation. Water samples from the vertical cross-section of the filtration columns were collected once a week. The effectiveness of removing organic compounds from water was evaluated on the basis of three main indicators of organic pollutants: $\mathrm{COD}\left(\mathrm{KMnO}_{4}\right)$, total organic carbon (TOC) and $\mathrm{UV}_{254}$ absorbance. In addition, the presence of psychrophilic bacteria in the bed was investigated using the heterotrophic plate count method (HPC). Water samples for microbiological analyses were sterilely collected once a week from the vertical section of the filtration columns. The identification of microorganisms was carried out using the automated system Vitek 2 Compact (bioMerieux). Identification was performed using bacterial identification charts (GN).

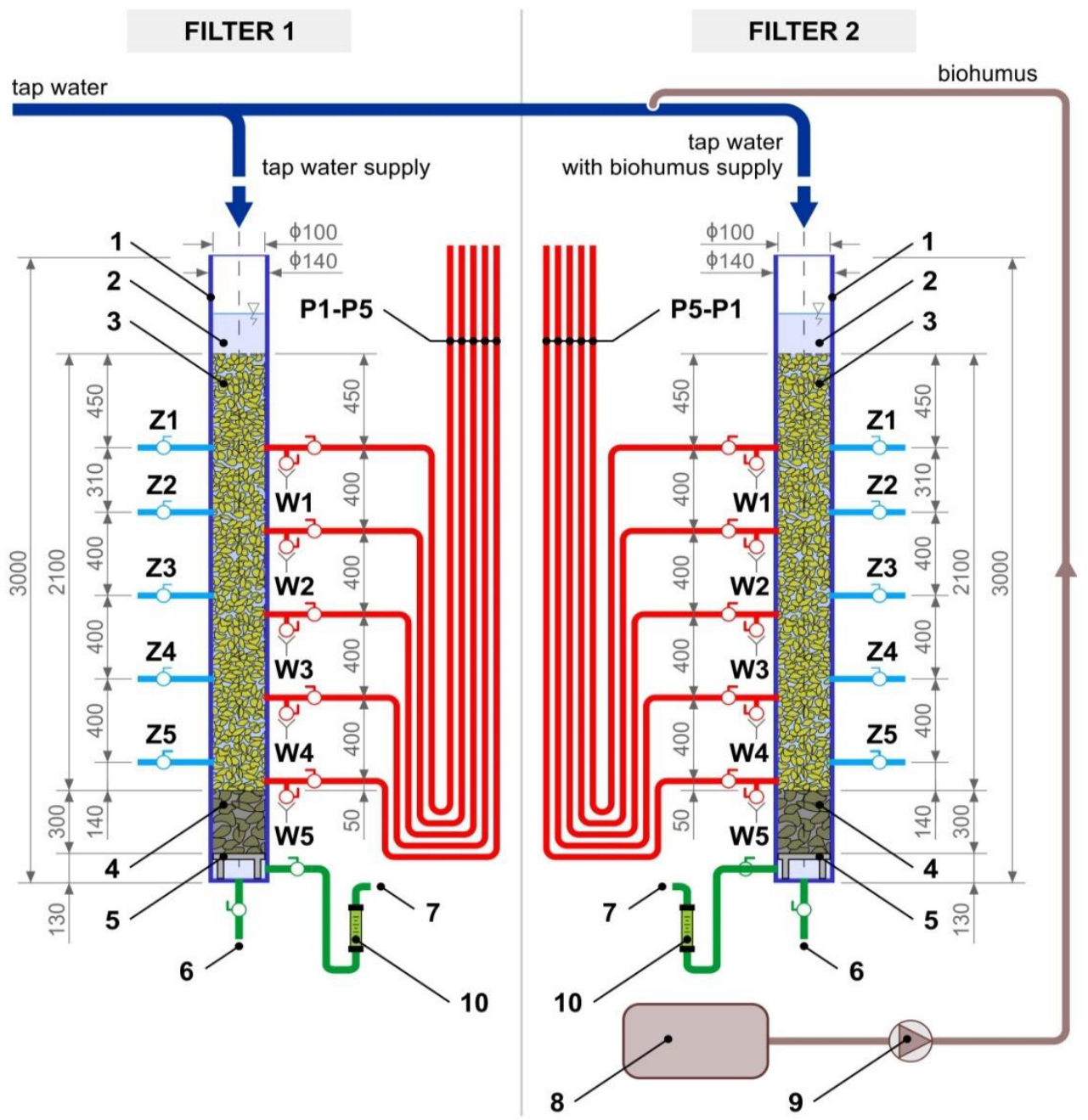

Fig. 1. Pilot plant with two identical filtration columns:

1 - water jacket, 2 - filtration column, 3 - filter bed, 4 - gravel supporting layer, 5 - drainage,

6 - backwash water, 7 - outlet, 8 - biohumus tank, 9 - diaphragm pump, 10 - rotameter,

P1-P5 - piezometers, W1-W5 water sampling points, Z1-Z5 filter bed sampling points. 


\section{Results and discussion}

In order to check which process is predominant in the entire filter bed, the Eberhardt, Madsen and Sontheimer index (EMS) was determined. This index is defined as the ratio of COD change $(\triangle \mathrm{COD})$ to the change of the dissolved oxygen concentration $\left(\Delta \mathrm{O}_{2}\right)$ during the flow of water through the bed $[17,18]$. The results of the EMS test for the technological start-up of both filters are shown in Figure 2.

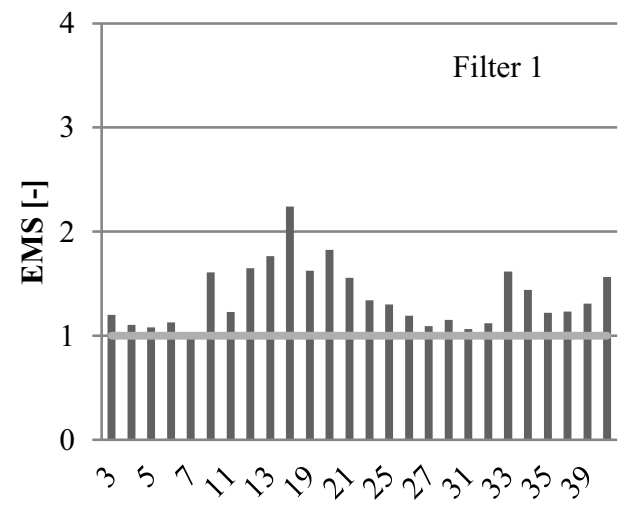

Filter operation time [day]

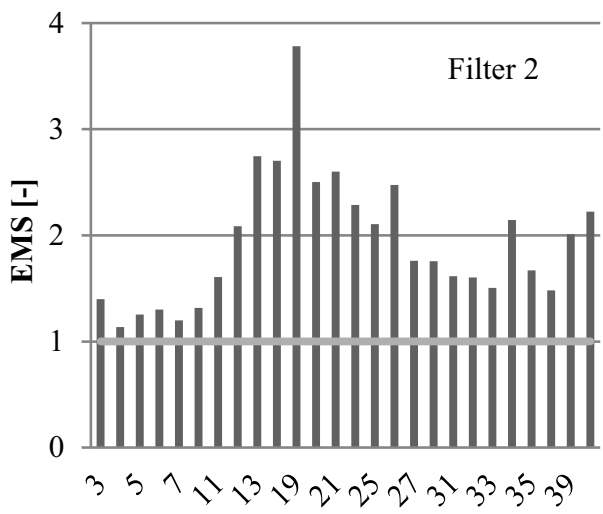

Filter operation time [day]

Fig. 2. Relationship between the sorption and biodegradation processes in Filter 1 and Filter 2.

The value of the EMS $>1$ confirms that the sorption process prevailed in both filters throughout the entire forty-day study period. Over time, when the adsorbed pollutants deplete the sorption capacity of the filter bed and a sufficient number of microorganisms develop in the filter, biodegradation will become the predominant process. The development of microorganisms in the filter bed is possible when appropriate conditions are ensured, i.e. the optimum temperature, oxygen access and sufficient nutrient content $[6,7,16]$. During the tests, the abovementioned parameters were controlled. The water temperature ranged from $14.1^{\circ} \mathrm{C}$ to $21.1^{\circ} \mathrm{C}$, the concentration of oxygen dissolved in water measured in the inflow was $4.72 \mathrm{mg} \mathrm{O} / 2 \mathrm{dm}^{3}$ and $\mathrm{pH}$ was 7.5 , on average. The average value of total organic carbon in the water flowing into Filter 1 was $5.7 \mathrm{mg} \mathrm{C} / \mathrm{dm}^{3}$, while in the modelled water $5.9 \mathrm{mg} \mathrm{C} / \mathrm{dm}^{3}$. The measured values confirm that the conditions in both filter beds were conducive to colonization by heterotrophic bacteria. During the research, microbiological analyses were carried out to detect the presence of psychrophilic bacteria. The obtained results are shown in Figure 3. Already on the $5^{\text {th }}$ day of the system operation, an increase in the number of bacteria in the samples of water collected from the filter profile, in relation to their number in the inflow was found. With time, the amount of bacteria living in the filter bed increased. In Filter 1, the amount of bacteria increased in relation to the inflow throughout the entire study period, while in Filter 2, an increase occurred in the initial period of research (on days 5 and 12). Later on, more bacteria were detected in the inflow than in the samples taken from the bed and from the outflow, which may indicate that the biofilm is very well attached to the bed. In total, more microorganisms were found in the bed of Filter 2, supplied with biohumus modelled water. The solution dosed was not sterile, therefore more bacteria capable of colonizing the deposit were found in the water supplying Filter 2 than in the case of Filter 1. The presence and growth of microorganisms indicates proper conditions of the process, mainly a sufficient content of organic compounds being nutrients for the bacteria. 


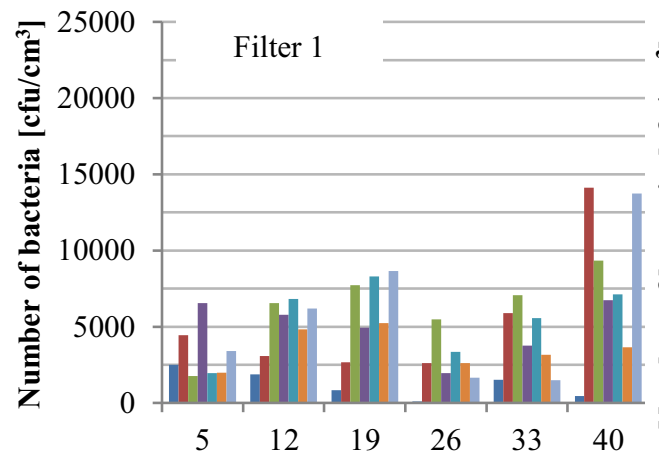

Filter operation time [day]

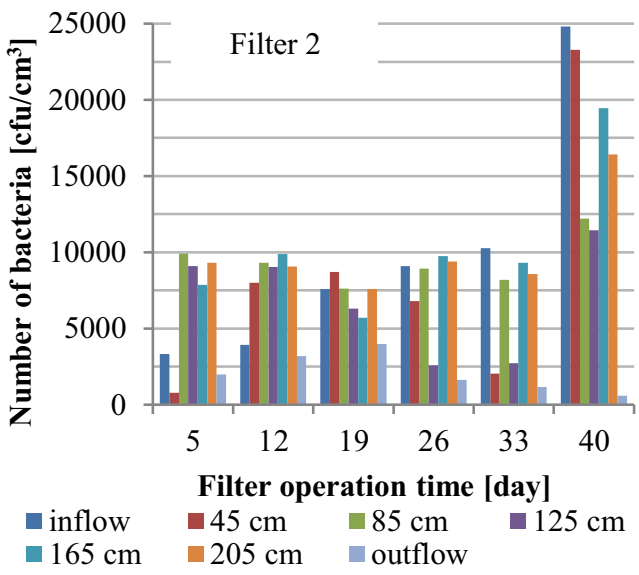

Fig. 3. Changes in the number of psychrophilic bacteria at different depths of Filter 1 and Filter 2.

The identification of the microorganisms showed the presence of Gram-negative bacteria in the beds of both filter columns. In both filters the Sphingomonas paucimobilis, Stenotrophomonas maltophilia, Acinetobacter lwoffii, Aeromonas salmonicida strains were identified. In Filter 1 the Achromobacter denitrificans were also detected. In Filter 2 fed with water modified with biohumus, other strains were detected, including Pseudomonas fluorescens. The differences in microorganisms inhabiting the two beds are undoubtedly related to the different bacteriological composition of the water feeding the filtration columns. No specimens from the Enterobacteriaceae family which are hazardous to human health were isolated from the collected samples. The identified strains are different from the ones found in the filter bed during the research in 2015 [6].

The study was carried out for a period of 40 days which turned out to be too short for the development of biofilm capable of biodegradation across the filter section. The earlier inoculation of the bed with backwashings from the biologically active filters has a positive effect on the development of biofilm in the filter bed. The backwashings contain large amounts of biofilm bacteria which produce a layer of organic substances - extracellular polymeric substances (EPS) (polysaccharides, proteins, nucleic acids, lipids) facilitating the adhesion of bacteria to the bed [9]. In filters in which the bed had been previously inoculated, the biodegradation process took place from the first day of the system operation, i.e. after cutting off the supply of recirculated backwashings [6, 7]. The backwash water recirculation with optimal nutrient composition lasted for 16 days.

The waters supplied to the test system i.e. tap water from the Poznan waterworks supplied Filter 1 and water contaminated with the biohumus solution supplied to Filter 2, had variable $\mathrm{COD}\left(\mathrm{KMnO}_{4}\right)$. In the inflow to Filter 1, the $\mathrm{COD}\left(\mathrm{KMnO}_{4}\right)$ of water ranged from 4.6 to $6.3 \mathrm{mg} \mathrm{O} / \mathrm{dm}^{3}$, while in the case of Filter 2, the values of the same parameter in the inflow were slightly higher and ranged from 4.7 to $6.6 \mathrm{mg} \mathrm{O} / \mathrm{dm}^{3}$. Minor differences in the content of organic substances in the inflow to both filters, despite the dosing of biohumus into the water feeding the filtration column 2 , were associated with problems with biohumus mixing in the modelled water tank. The problems were solved in the further course of the pilot installation operation. The $\mathrm{COD}\left(\mathrm{KMnO}_{4}\right)$ of water, due to the flow through the WG-12 carbon bed, decreased in both analysed cases. The $\mathrm{COD}\left(\mathrm{KMnO}_{4}\right)$ measured in the outflow from Filter 1 ranged from 0.02 to $0.40 \mathrm{mg} \mathrm{O} / \mathrm{dm}^{3}$, while from Filter 2, from 0.08 to $0.50 \mathrm{mg} \mathrm{O} / \mathrm{dm}^{3}$ (Fig. 4). The parameter decreased significantly after filtration through a $45 \mathrm{~cm}$ thick layer of the bed. The efficiency of COD reduction down to the depth of $45 \mathrm{~cm}$ versus the total efficiency ranged from $97 \%$ to $67 \%$ for Filter 1 and 
from $91 \%$ to $64 \%$ for Filter 2. In both cases the upper bed layer efficiency decreased over time. The recorded $\mathrm{COD}\left(\mathrm{KMnO}_{4}\right)$ reduction efficiency was very high for both filters, in excess of $95 \%$ on average. Throughout the entire research period, the efficiency was never below $93 \%$. Based on that it was concluded that the fresh WG-12 activated carbon was highly effective in reducing the content of organic compounds in water through the sorption process.

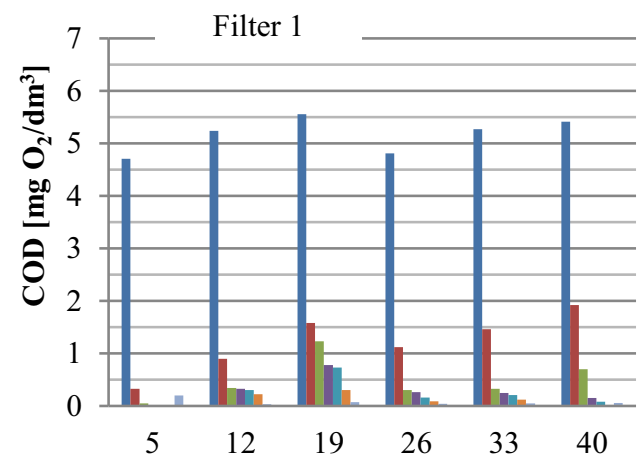

Filter operation time [day]

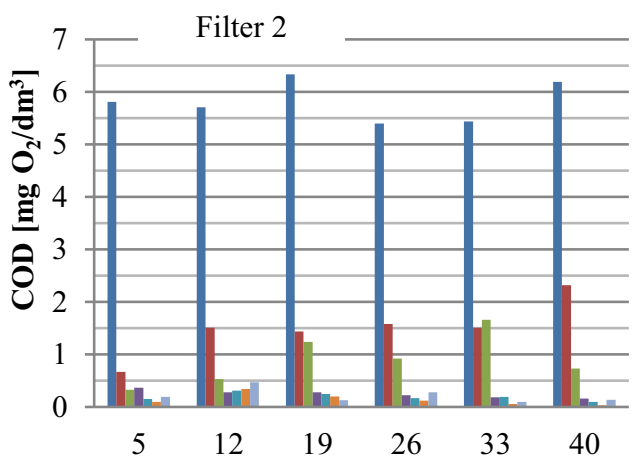

Filter operation tme [day]

$$
\square \text { inflow } \quad \square 5 \mathrm{~cm} \quad \square 5 \mathrm{~cm} \quad 125 \mathrm{~cm}
$$

$\square 165 \mathrm{~cm} \quad \square 205 \mathrm{~cm} \quad$ outflow

Fig. 4. COD of water at different depths of Filter 1 and Filter 2.

The TOC values in the inflow, outflow and in the vertical cross-section of filters are presented in Figure 5. The average TOC value in water supplied to Filter 1 was $5.7 \mathrm{mg} \mathrm{C} / \mathrm{dm}^{3}$, while in the case of water treated with the solution of humic compounds amounted to $5.9 \mathrm{mg} \mathrm{C} / \mathrm{dm}^{3}$. Biohumus caused a slight increase in that parameter, which was associated with its poor mixing in the biohumus tank. On the outflow from both filters, the value of TOC was the same and amounted to $0.5 \mathrm{mg} \mathrm{C} / \mathrm{dm}^{3}$. This indicates the high efficiency of the sorption process during the filtration period.

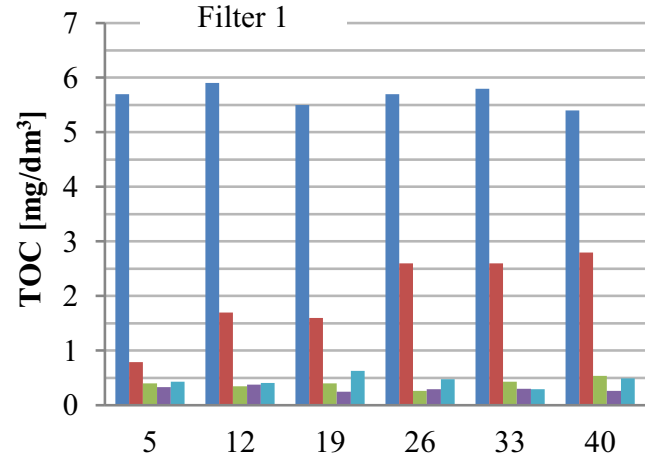

Filter operation time [day]

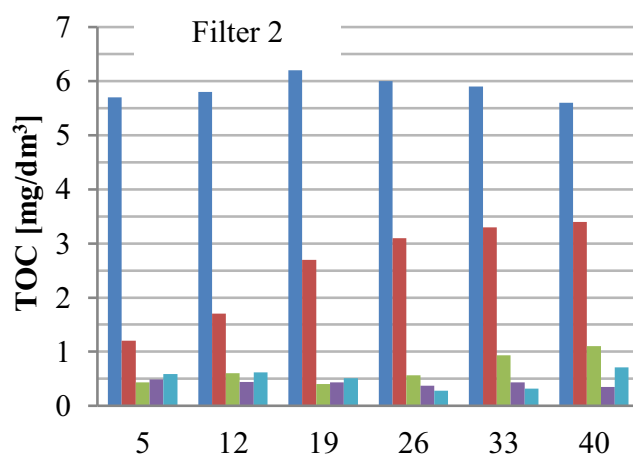

Filter operation time [day]

$\square$ inflow $\square 45 \mathrm{~cm} \square 125 \mathrm{~cm} \square 205 \mathrm{~cm} \square$ outflow

Fig. 5. TOC in the water at different depths of Filter 1 and Filter 2.

The UV absorbance at $254 \mathrm{~nm}$ at different bed depths is shown in Figure 6. The mean value of this parameter at Filter 1 inlet was $0.22 \mathrm{~m}^{-1}$. The flow through the WG-12 active 
carbon bed caused a decrease in $\mathrm{UV}_{254}$ absorbance at the outlet to the value of $0.00 \mathrm{~m}^{-1}$. This result was already obtained at a bed depth of $45 \mathrm{~cm}$. For Filter 2, the average $U_{254}$ value in the inflow was $0.29 \mathrm{~m}^{-1}$. As a result of the flow through the filter bed, the water was purified and reached an average value in the outflow of $0.04 \mathrm{~m}^{-1}$. An exception to that rule was the 19th day of the filter operation. The increase in $\mathrm{UV}_{254}$ absorbance on that day may indicate the detachment of fragments of the biological film formed on the activated carbon surface.

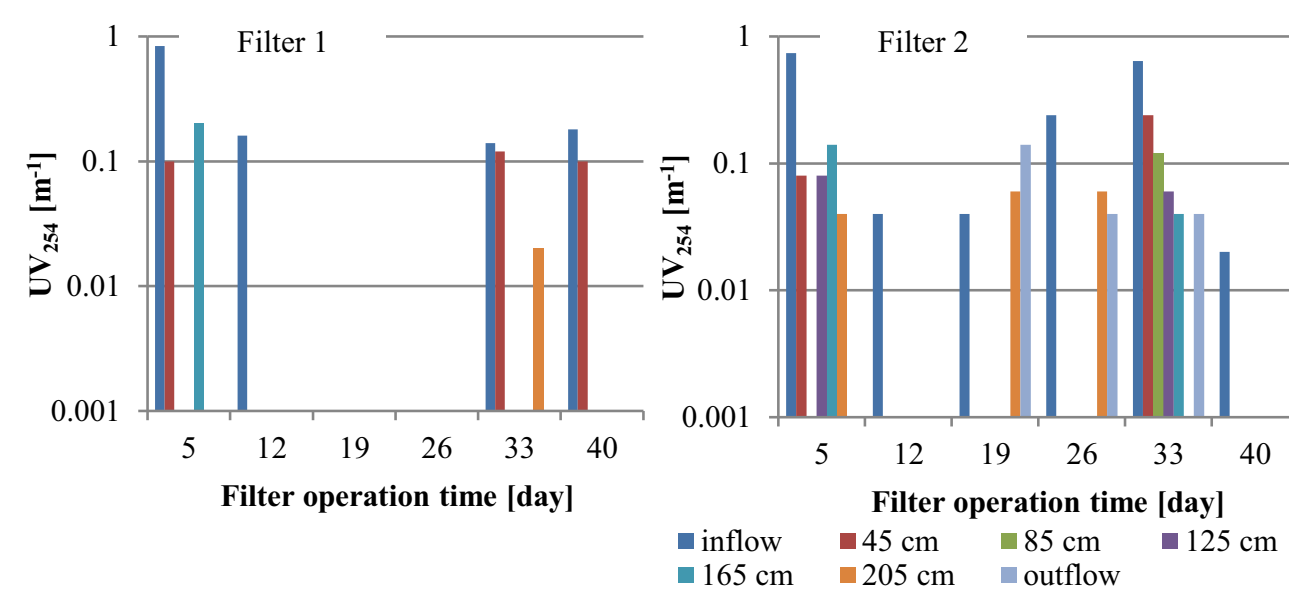

Fig. 6. Changes in $\mathrm{UV}_{254}$ absorbance at different depths of Filter 1 and Filter 2.

\section{Summary}

Removal of organic compounds from water during the technological start-up of rapid carbon filters operated on a pilot scale showed that during the first 40 days of the system operation, the sorption process prevailed in the filter bed.

The efficiency of reducing the organic matter content through a sorption process in the fresh WG-12 activated carbon filter bed during the first 40 days of the filter operation was as follows: for COD $\left(\mathrm{KMnO}_{4}\right) 96-97 \%$, for TOC $91-92 \%$ and for $\mathrm{UV}_{254}$ absorbance $100 \%$.

The identification of microorganisms showed the presence of Gram-negative bacteria in the beds of both filter columns. Differences in the strains inhabiting both deposits were undoubtedly related to the different bacteriological composition of the water feeding the filtration columns.

When comparing the results of current research, to the research carried out in 2015 [6], it can be concluded that:

- the strains of bacteria identified in the filter bed are different,

- there is a significant difference (17 days) in the length of time during which sorption prevailed over biodegradation.

Such differences occurred, despite the use of the same commercial carbon WG-12, with the same declared parameters. 


\section{References}

1. S. A. Baghoth, Characterizing natural organic matter in drinking water treatment process and trans, UNESCO-IHE PhD Th. (2012)

2. I. Krupińska, Zeszyty Naukowe Uniwersytetu Zielonogórskiego. Inżynieria Środowiska 28, 148, 55-72 (2012)

3. O. Gibert, B. Lefevre, A. Teuler, X. Bernat, J. Tobella, Journal of Water Process Engineering 6, 64-71 (2015)

4. M. Świderska-Bróż, M. Wolska, Rocz. Ochr. Sr. 33, 4, 77-80 (2011)

5. W. Adamski, M. Szlachta, Technologia Wody 1, 17-21 (2011)

6. D. Holc, A. Pruss, M. Michałkiewicz, Z. Cybulski, Rocz. Ochr. Sr. 18, 2, 235-246 (2016)

7. D. Holc, A. Pruss, M. Michałkiewicz, Z. Cybulski, Zaopatrzenie $w$ wodę jakość i ochrona wód (Wyd. PZITS, Poznań, 2016)

8. P. Kołaski, A. Wysocka, A. Pruss, I. Lasocka-Gomuła, M. Michałkiewicz, Z. Cybulski, Dezynfekcja wody, zagrożenia, wyzwania, nowe technologie (Wyd. AGH, Kraków, 2017)

9. D. R. Simpson, Water Res. 42, 2839-2848 (2008)

10. L. Han, W. Liu, M. Chen, M. Zhang, S. Liu, R. Sun, X. Fei, Water Res. 47, 4861-4868 (2013)

11. A. Lis, Ł. Pasoń, L. Stępniak, Inżynieria i Ochrona Środowiska 19, 3, 4113-425 (2016)

12. D. Papciak, A. Pietrzyk, Dezynfekcja wody, zagrożenia, wyzwania, nowe technologie (Wyd. AGH, Kraków, 2017)

13. O. Gibert, B. Lefevre, M. Fernandez, X. Bernat, M. Paraira, M. Calderer, X. Martinez-Llado, Water Res. 47, 1101-1110 (2013)

14. H. Xiang, X. Lu, D. Zhang, F. Yang, L. Yin, G. Zhu, W. Liu, Chinese Journal of Applied and Environmental Biology 18, 4, 642-646 (2012)

15. M. Wolny, E. Kudlek, M. Dudziak, Inżynieria środowiska - młodym okiem. T. 30, Wody powierzchniowe $i$ podziemne (Wyd. Oficyna Wydawnicza Politechniki Białostockiej, Białystok, 2017)

16. A. Pruss, M. Komorowska-Kaufman, B. Mądrecka, Water Supply and Wastewater Disposal (Wyd. Lublin University of Technology, Lublin, 2018)

17. P. Olesiak, L. Stępniak, Interdyscyplinarne zagadnienia $w$ inżynierii $i$ ochronie środowiska (Wyd. Oficyna Wydawnicza Politechniki Wrocławskiej, Wrocław, 2014)

18. D. Papciak, J. Kaleta, A. Puszkarewicz, B. Tchórzewska-Cieślak, Journal of Ecological Engineering 17, 3, 119-124 (2016) 